\title{
Nottingham Grade 1
}

National Cancer Institute

\section{Source}

National Cancer Institute. Nottingham Grade 1. NCI Thesaurus. Code C138987.

Total Notting ham scores of 3, 4, or 5 . 